two years ago in Kyoto, at which Japan, together with the European Union, successfully steered a middle course between the positions of the United States and developing countries.

Matsuura's appointment is the result of an intense campaign by the Japanese government, which is keen to raise its profile in international affairs. He had the active support of physicist Akito Arima, formerly the president of the University of Tokyo, and until recently his country's minister of education and research. And the Japanese prime minister, Keizo Obuchi, an old schoolfriend, is said to have lobbied several European heads of state on Matsuura's behalf.

This campaign has led to speculation that Japan may have promised additional aid to some developing countries in return for their support for Matsuura's nomination. Matsuura has extensive experience of dealing with such countries, having been an architect of Japan's aid policies during the 1980s.

But he is said to have performed only moderately well in his interview with the executive board, and his appointment is widely seen as a vote for the Japanese government, rather than the ambassador personally. Japan is Unesco's largest donor country, and contributes 25 per cent of the organization's $\$ 544$ million annual budget. David Dickson and Peter Pockley

\title{
US Congressman boycotts science meeting with China
}

\section{San Diego}

The first in a planned decade-long series of meetings between US and Chinese scientific leaders was marred this week by the withdrawal of a powerful US Congressman, citing allegations of Chinese spying and illegal technology uses.

James Sensenbrenner (Republican, Wisconsin), chairman of the House Science Committee, cancelled his plans to attend the Sino-US Joint Science Policy Seminar as the delegation was leaving for the four-day meeting with representatives of the National Natural Sciences Foundation of China, due to open in Beijing last Sunday (24 October).

Sensenbrenner contacted Rita Colwell, the director of the National Science Foundation (NSF), the meeting's sponsor, asking her to cancel the delegation's trip because of continued Chinese provocations. "A seminar with senior officials from the White House and Congress could convey to the Chinese a business-as-usual attitude in our relationship on science and technology," Sensenbrenner said in a statement.

The Congressman was angered by the indictment earlier this month of the China National Aero-Technology Import and Export Corporation and the McDonnell
Douglas Corporation for the alleged illegal transfer of US defence technology to a Chinese missile factory.

$\mathrm{He}$ also quoted allegations of Chinese spying involving nuclear bomb secrets from the Los Alamos National Laboratory in New Mexico (see Nature 399, 395; 1999), and "mischaracterizations" by Chinese officials visiting Congress this month for the first time since the Tiananmen Square conflict.

But Colwell declined to call off the trip, saying in a statement that "I've consulted widely with colleagues within and without [President Bill Clinton's] administration, and there is unanimity that the seminar is not linked to Sensenbrenner's specific concerns".

Colwell said the event "reflects the principle of free circulation of scientists and our continuing commitment to an open discussion of issues of common scientific interest".

US participants at the seminar included representatives from the NSF, the National Institutes of Health, the National Academy of Engineering and several universities. The latter included Richard C. Atkinson, president of the University of California - ironically, the institution that manages the Los Alamos laboratory from which nuclear secrets are alleged to have been stolen. Rex Dalton

\section{European biologists unite to lobby for more money}

\section{Munich}

A group ofleading European molecular biologists is to launch a new initiative, called the European Life Sciences Forum (ELSF), to present a united view to politicians of the needs of the basic research community in Europe.

Frank Gannon, director of the Heidelberg-based European Molecular Biology Organization (EMBO), told the Munich Symposium on Cell Dynamics last week that the forum was necessary because of the fragmentation of the community's voice.

This fragmentation had weakened the impact of researchers on the European Union's fifth five-year Framework programme of research (FP5), which started this year, he said. "EMBO was one of very many life sciences organizations in Europe which individually advised the European Commission on how it should structure the programme, yet we saw no evidence of EMBO's input in the final design."

Given the "exponentially increasing" economic and social importance of life sciences, and the increasing demands of the biotech-

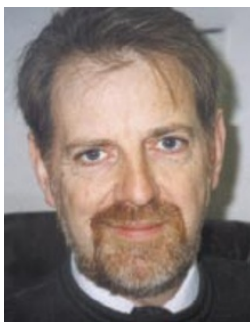

nology industry for advances in basic research, the life sciences need "a step up in funding, not incremental increases, as is currently the case in Europe," said Gannon.

One of the first tasks Gannon: life sciences of ELSF, whose manineed a single voice. festo will be published on the Internet, will be to establish dialogue with the European Commission and coordinate a single input into the sixth Framework programme on behalf of all European basic researchers in the life sciences when such discussions begin in the next two years.

Don Cleveland, a professor at the University of California at San Diego, told the Munich meeting that a recent commitment to doubling the budget of the National Institutes of Health by the US Congress had been largely due to a campaign by scientists in the US societies for cell biology, biochemistry and biophysics.

^๑ 1999 Macmillan Magazines Ltd
Ten years ago, said Cleveland, when the American Society of Cell Biology was still very small, it started to spend a significant proportion of its budget on paying a fulltime member of staff to "worry about public advocacy", as well as the services of a professional lobbyist in Washington. "At the time, some scientists said we were spending too much," he said. "But it paid off."

Other scientists at the meeting pointed to the success of Greenpeace's well-funded campaigns in Europe — such as that against genetically modified foods - which they said urgently needed to be matched by similarly competent campaigns by scientists.

Gannon pointed out that the task of lobbying is more complicated in Europe than in the United States. "We have to lobby in ten different languages and in twice as many political centres of power," he said.

But he said that scientists had themselves to blame for inadequate funding of life sciences in Europe "because we have never been able to come up with the simple sort of message that politicians can understand and convey to their constituents". Alison Abbott 